\title{
ANALYSIS OF STEEL PRODUCTION AND STEEL USE IN THE NATIONAL ECONOMY
}

\author{
Bożena GAJDZIK \\ Silesian University of Technology, Gliwice; bozena.gajdzik@ polsl.pl, ORCID: 0000-0002-0408-1691
}

Purpose: The publication contains an analysis of steel production and consumption of steel in the national economy in the period from 2000 to 2018.

Design/methodology/approach: The analysis is divided into three parts of the realized research. The first part is about trends of steel production; the second analysis is about average steel consumption; while the last part is about the influence of the volume of steel imports on the level of domestic consumption of steel. Assessed quantities of steel production and steel consumption are compared with basic macroeconomic indicators in Poland.

Findings: The average annual dynamics of basic macroeconomic indicators in Poland from 2000 to 2018 were as follows: the largest decrease in the amount of steel produced and consumed in Poland was recorded in 2009, this was due to the effects of the global economic crisis; the average annual volume of steel production in Poland in the period from 2000 to 2018 was 9 million tonnes, in the same period, the average annual steel consumption in Poland was nearly 8.5 million tonnes, and the average annual steel import to Poland was 334 thousand tonnes; the average annual dynamics of the volume (quantity) of steel production in Poland in the period was almost $+2 \%$ and was lower than the average annual dynamics of the amount of steel consumed in Poland by $0.2 \%$; the average forecast of steel consumption in Poland in period from 2019 to 2023 will be 11.2 million tonnes.

Originality/value: The result of the analysis can be used by market experts or managers to plan production in their enterprises.

Keywords: steel industry, steel production, steel consumption, steel imports.

Category of the paper: research paper.

\section{Introduction}

Steel is a basic structural material with very wide application by other industries. Enterprises use steel as an input material (raw material) in the production process for the production of other products, e.g. cars, machines, household appliances or as a construction material in construction. Enterprises operate in an extremely complex environment that is also characterized by a high degree of evolutionary change. The steel industry is particularly 
vulnerable to macroeconomic changes. Business cycles (an increase or decrease in basic macroeconomic indicators in the economy) shape periodic fluctuations in the long-term over the amount of steel production and consumption by individual sectors of industry in the national economy. The largest user of raw steel is the "Metals" section, and the largest user of finished steel products is construction (over 40\%), other places are occupied by: the engineering industry (15\%), automotive (about 12\%), transport equipment (4\%), household appliances (3.5\%) and other manufacturing sectors, e.g. electrical equipment, electronics.

The steel market in Poland consists of steel producers (integrated steel mills and steel mills using electric furnaces) and metal processing companies (processing steel semi-finished products into final steel products). After the restructuring of the steel industry in Poland in the 1990s and the creation of the foundations of a market economy in the country, the steel industry strengthened year by year (among other reasons, by implementing technological investments classified as innovative) (Szulc et al., 2011; Gajdzik, 2013c; Ostrowski, 2009; Report, 2007). Foreign capital, which is the owner of the largest steel mills in Poland, has been operating on the Polish market since the privatization of steel mills by the Polish government. After Poland's accession to the EU, the steel industry in Poland adopted certain restrictions regarding, among others, production efficiency, product range and the impact of steel mills on the environment, as well as resource consumption (Szulc, 2014). Currently, the steel industry in Poland is innovative and competitive in relation to other steel mills operating within the European market (Gajdzik, 2013b, 2018). Open-hearth furnaces used for steel smelting have been withdrawn, and the production process is carried out using blast furnaces and converters (BOF technology) (an integrated process) and arc or induction electric furnaces (EAF technology). In 2018, 10.2 million tons of crude steel was produced in Poland. The share of steel from the integrated process was higher than that of steel produced in the electric process. In 2018, 5.4 million tonnes of converter steel and 4,8 million tonnes of electric steel were produced (Report, 2019).

The demand for steel by individual industries is conditioned by the situation in the national economy and even in the global economy. For several years, Poland's economic situation has been good - high economic indicators: GDP, consumption, investment, export, import. The stable economic situation in the country is conducive to steel production and its consumption. Poland's steel industry and steel-consuming sectors are efficient and competitive upon the global market. In recent years, the steel industry and the largest steel consumers: the car and machine industries, have recorded the highest dynamics and increases in production volume. The value of sold production of the steel sector in Poland constitutes about $3 \%$ of total industrial production.

The largest decrease in steel production in Poland and its consumption was recorded during the economic crisis in 2008-2009 (Gajdzik, 2013a, 2014). After the crisis, the Polish steel sector managed to rebuild its position in the national economy. Currently, the steel sector in Poland is 
composed of 29 steel and steel products producers (the number of enterprises comes from the ranking list - List 500).

\section{The analysis of the volume of steel produced in Poland in 2000-2018}

The analysis of the volume of steel produced in Poland in 2000-2018 is presented against the background of the macroeconomic situation. The characterizing of the economic situation is made on the basis of the following indicators: GDP, consumption, investment, export, import. The indicators were calculated as the dynamics of changes in individual areas (year on year) in percent [\%] - formula 1 (Bednarski, 2007). Figure 1 shows the volume of steel production in Poland in 2000-2018. In Figure 2, the dynamics of macroeconomic indicators: GDP, consumption, investment, export, import are laid out. The charts obtained were compared for the impact of the economic situation in the country on the level of steel production in the analyzed period.

Formula 1:

$D_{z}=\frac{\left(\mathrm{z}_{\mathrm{t}}-\mathrm{z}_{\mathrm{t}-1}\right)}{\mathrm{z}_{\mathrm{t}-1}} \times 100 \%$

where:

$\mathrm{D}_{\mathrm{z}}$ - indicator of the dynamics of the given $\mathrm{Z}$ position,

$Z_{t}$ - value of the given $\mathrm{Z}$ position in the current period $(\mathrm{t})$,

$\mathrm{Z}_{\mathrm{t}-1}$ - value of the given $\mathrm{Z}$ item in the previous period $(\mathrm{t}-1)$.

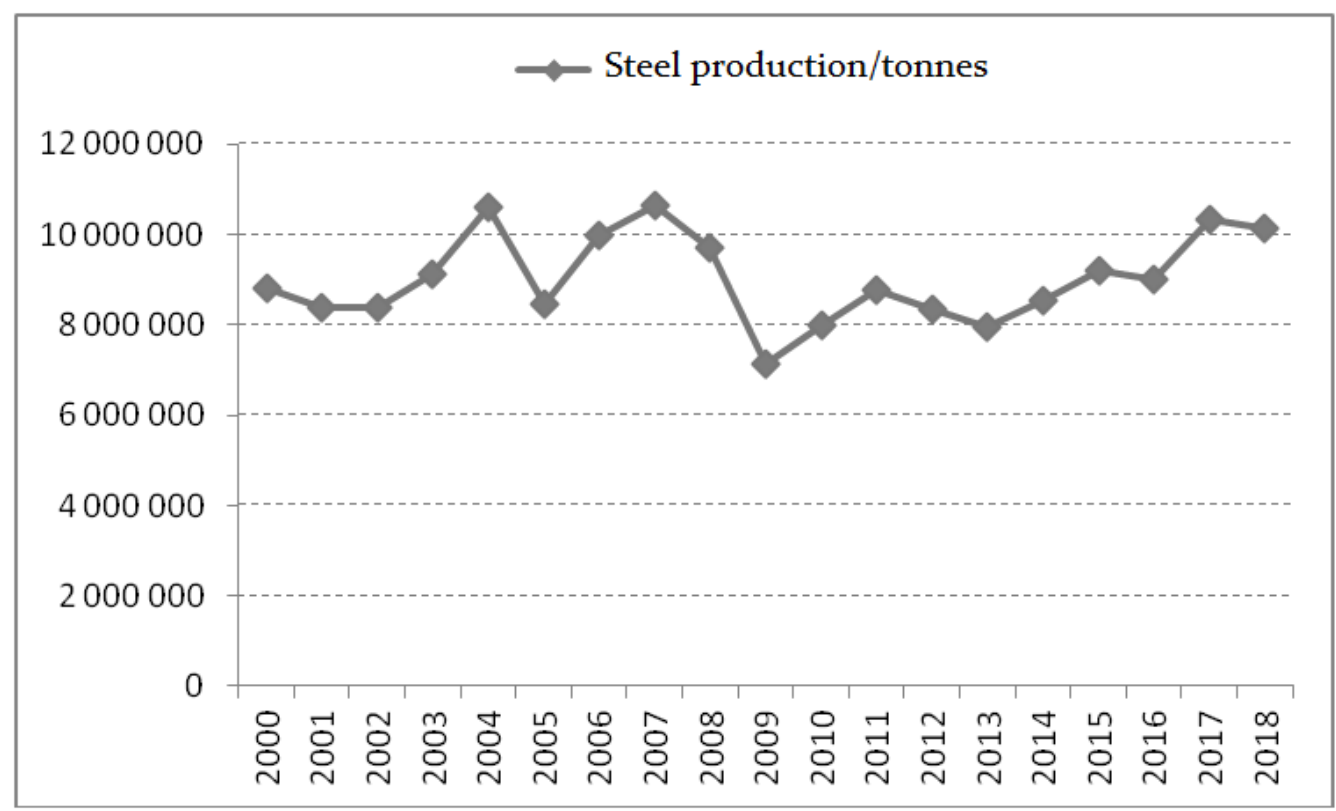

Figure 1. The volume of steel produced in Poland in the period from 2000 to 2018. Source: own analyses on the basis of data from Polish Steel Assoctaion in Katowice. 
In the period under analysis, 9 million tonnes of crude steel was produced in Poland on an average annual basis. Production at a level higher than 10 million tonnes was in 2004 and 2007 and in the last two years: 2017-2018. The lowest production level was in 2009 at 7.1 million tonnes, the highest was 10.6 million tonnes in 2007.

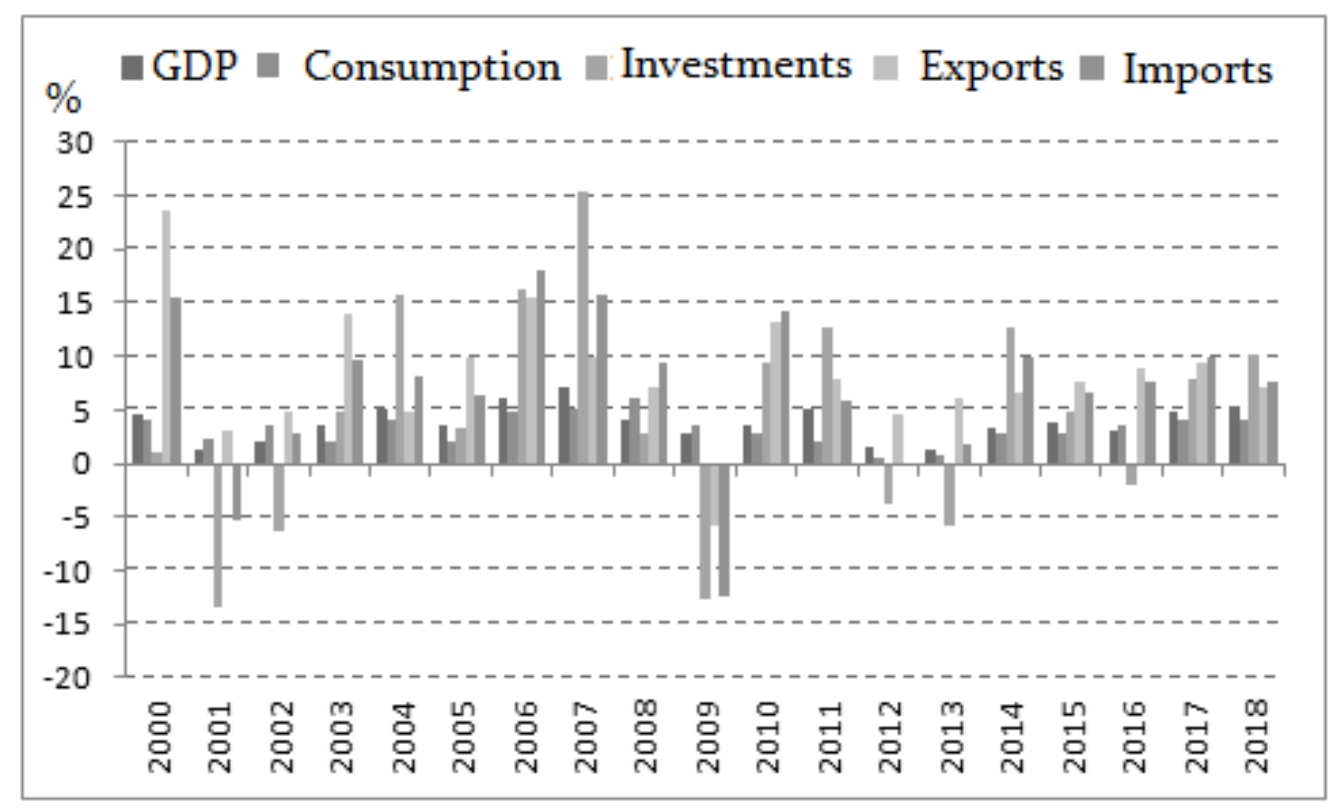

Figure 2. The level of macroeconomic indicators in Poland in the period from 2000 to 2018 (y-o-y). Source: own analyses on the basis of data from Polish Steel Assoctaion in Katowice.

On the basis of macroeconomic indicators (Fig. 2), the advantage of positive dynamics over negative dynamics was observed. The periods in which the dynamics of changes were positive (economic growth) were: 2000, 2003-2008, 2010-2011, 2014-2015, 2017-2018. A high negative decrease in the analyzed macroeconomic values was recorded in 2009 (the global economic crisis reaches Poland). Some indicators fell in 2001-2002, 2009, 2012-2013 and 2016. Negative investment dynamics were in: 2001, 2002, 2009, 2012, 2013 and 2016. Negative import dynamics appeared in 2001 and 2009, and exports only in 2009. The average annual dynamics of basic macroeconomic indicators in Poland in the period from 2000 to 2018 was as follows:

- GDP: $+3,8 \%$,

- Consumption: $3,2 \%$,

- Investments $4,4 \%$,

- Exports: 8,4\%,

- Imports: $6,9 \%$.

The macroeconomic situation was compared with steel production, for this purpose, the dynamics of steel production changes (year to year/y-o-y) in the period 2000-2018 were calculated (Figure 3). 


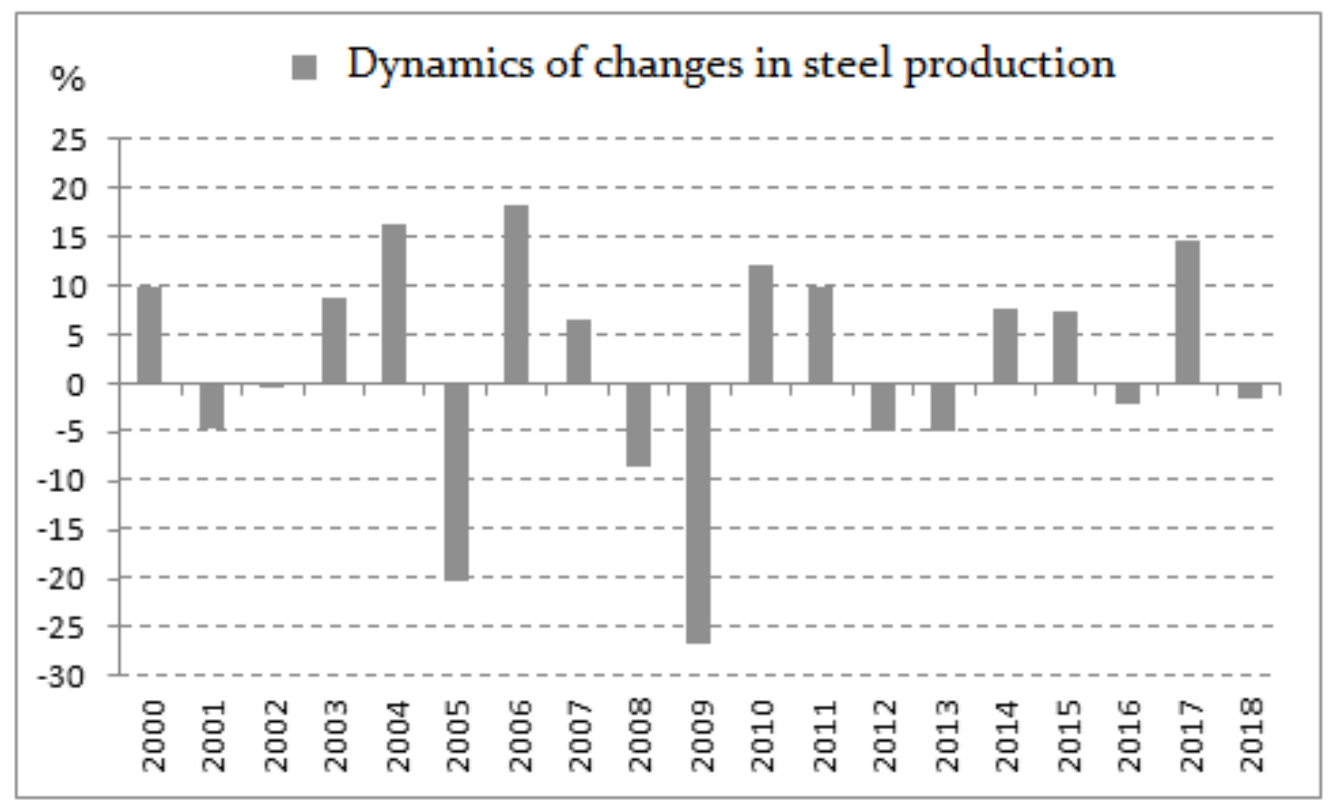

Figure 3. The dynamics of changes in steel production in Poland in the period from 2000 to 2018. Source: own analyses on the basis of data from Polish Steel Assoctaion in Katowice.

The average annual dynamics of changes in the size (quantity, volume) of produced steel in the analyzed period was about $2 \%$ and were, over all, positive (increase in steel production in 2000-2018). Based on a detailed summary of the dynamics of steel production volume in Poland in 2000-2018, there were years in which the dynamics of change was positive (economic growth) and periods with negative dynamics of change. Positive dynamics were evident in 2000, in 2003-2004, 2006-2006, 2010-2011, 2014-2015 and 2017. A high negative decrease in the dynamics of production volume was recorded in 2005 and in the period from 2008 to 2009 (effects of the global economic crisis). Declines in production dynamics were also seen (although already lower) in the period from 2001 to 2002 and in the period from 2012 to 2013, as well as in 2016 and 2018. The highest increase in steel production was in 2006 (18.3\%), and the lowest in $2007(6.4 \%)$. The largest decrease in the dynamics of production volume was in 2009 and amounted to $-26.7 \%$, and the smallest negative dynamics of changes was in 2002 $(-0.4 \%)$. On comparing Figures 2 and 3, it should be noted that the negative dynamics of all economic (macroeconomic) categories corresponds to the negative dynamics of production volume. The conclusion, hence, is drawn that the current economic condition affects the volume of steel production. 


\section{Steel consumption in the national economy}

Steel consumption, i.e. its consumption, takes place in industry sectors using steel as a material (semi-finished product) at the entrance to the production system. Steel consumption in the industry language is referred to as "apparent use" (apparent use). To calculate the steel consumption as base material, the following formula is used:

Steel consumption $=$ steel production - exports + imports

The amount of steel consumption in Poland in the period from 2000 to 2018 is shown in Figure 4. The highest steel consumption in Poland (above 10 million tonnes of steel consumed per year) was in 2017-2018. The average annual steel consumption in the analyzed period was almost 8.5 million tonnes. A sharp decline in steel consumption occurred in 2009, which was the result of the impact of the global economic crisis on the Polish economy.

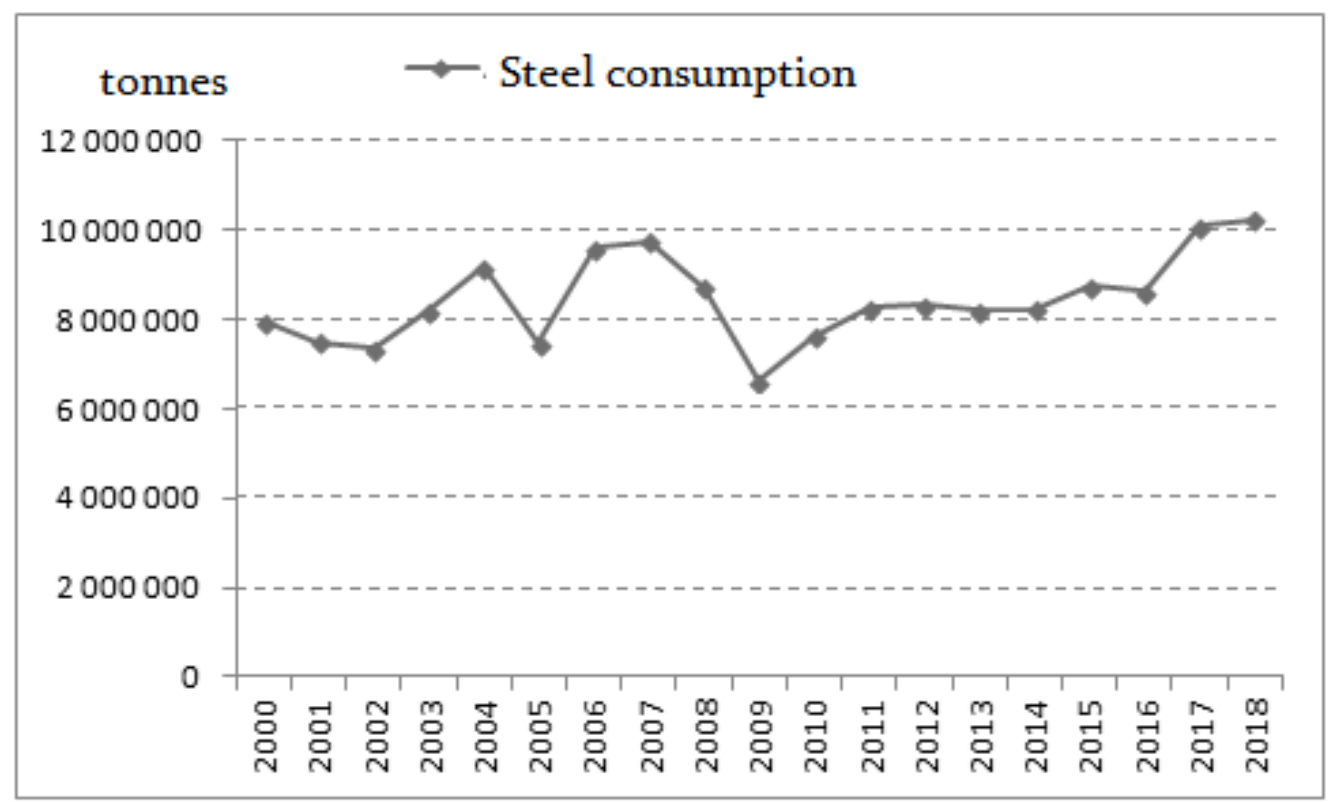

Figure 4. Steel consumption in Poland in the period from 2000 to 2018. Source: own analyses on the basis of data from Polish Steel Assoctaion in Katowice.

The average annual dynamics of apparent steel consumption in Poland in the period from 2000 to 2018 reached the level of $2.2 \%$ and was higher by $0.2 \%$ than the average annual dynamics of steel production. The highest increase in steel consumption was recorded in 2006 (28.1\%), and the lowest in $2014(0.5 \%)$. The largest decrease was in $2009(-24.1 \%)$, and the smallest in $2013(1.3 \%)$ - Figure 5. 


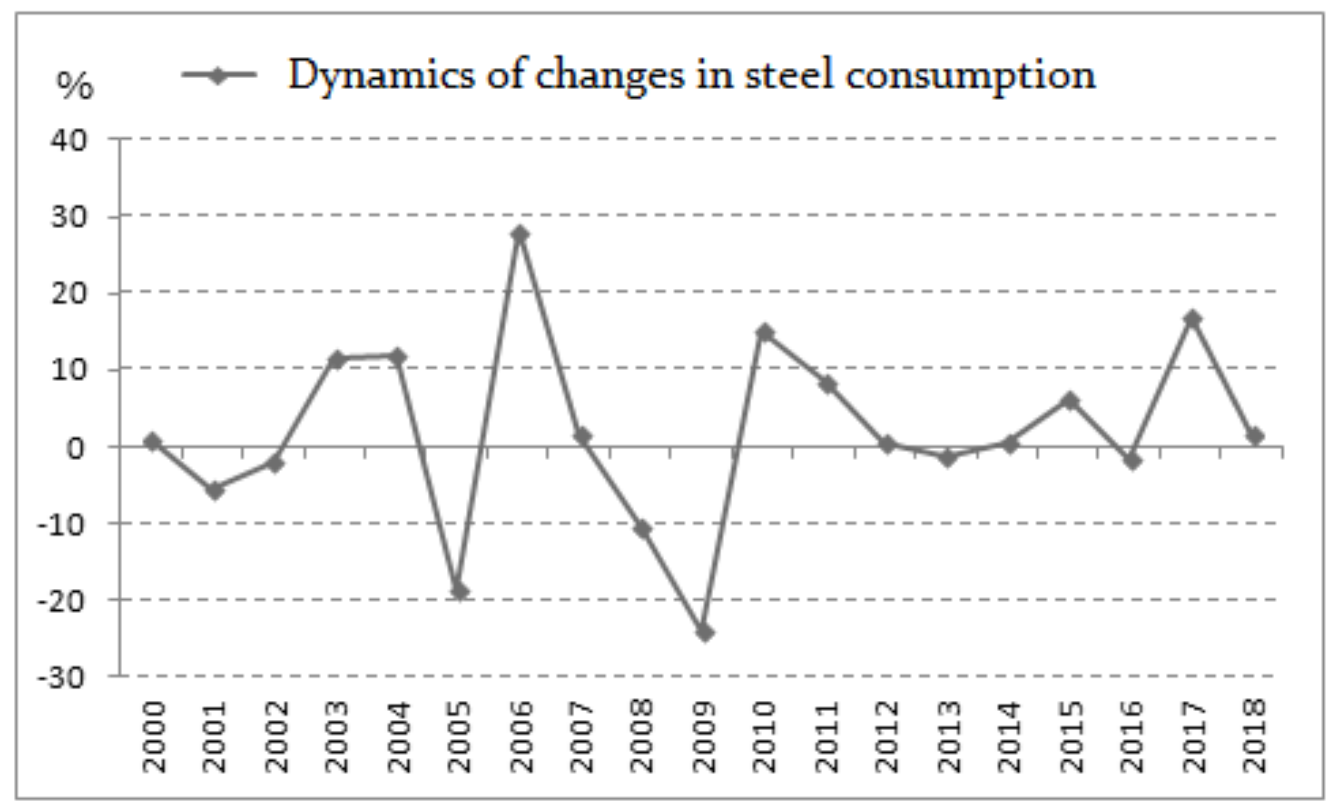

Figure 5. The dynamics of steel consumption in Poland in the period from 2000 to 2018 (y-o-y). Source: own analyses on the basis of data from Polish Steel Assoctaion in Katowice.

The dynamics of steel consumption in Poland in the period from 2000 to 2018 was compared with the dynamics of steel production (Fig. 6), and trend fluctuations (increase or decrease) were noted in the same periods, except for 2012 and 2018 - when the dynamics of production volume was negative and the dynamics of steel consumption was positive. The highest change rates for both studied phenomena were recorded in 2006, and the lowest in 2009.

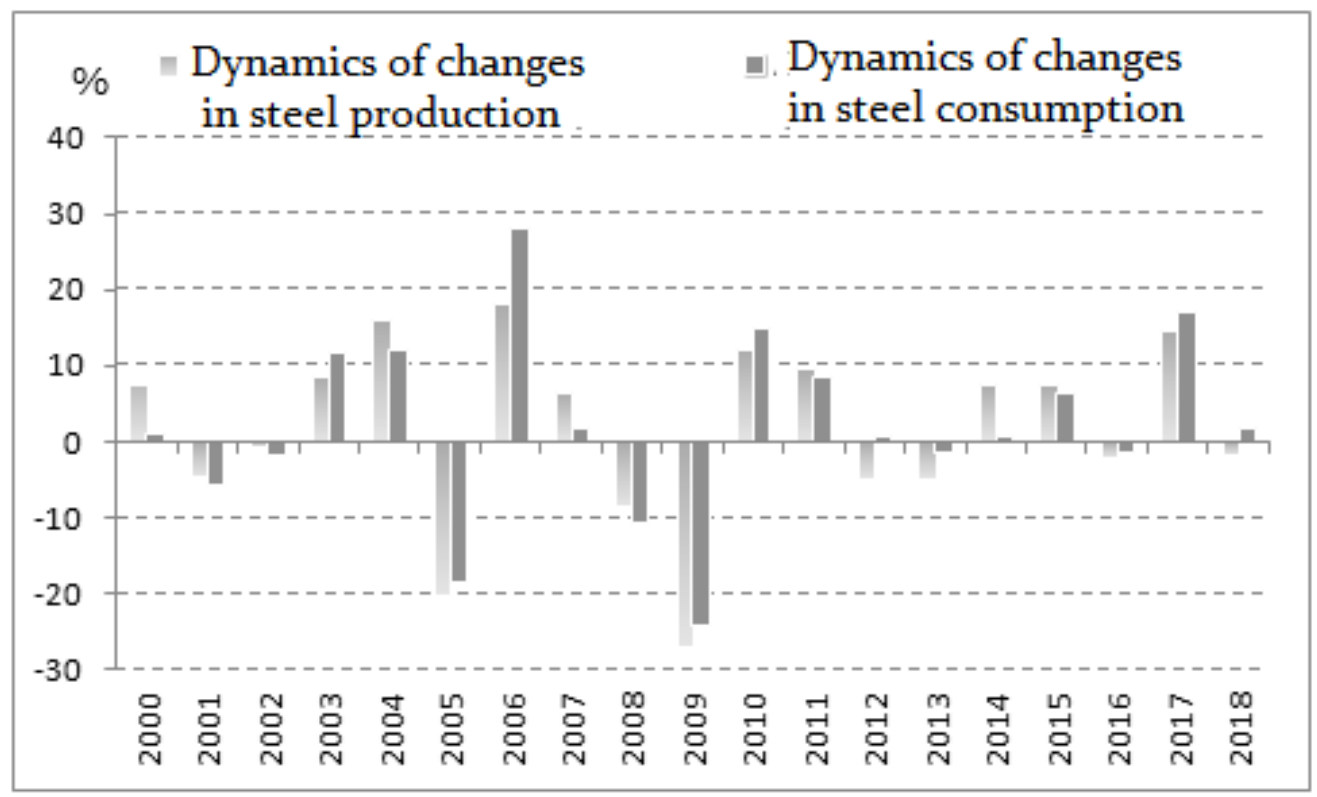

Figure 6. The dynamics of steel production and steel consumption in Poland in the period from 2000 to 2018 (y-o-y). Source: own analyses on the basis of data from Polish Steel Assoctaion in Katowice. 


\section{Influence of imports on steel consumption in Poland}

A higher demand for steel than the volume produced in the country is covered by steel produced in other countries. Thus, the import of steel products affects the level of steel consumption in the country. The volume of steel (semi-finished products) imports to Poland in the period from 2000 to 2018 is shown in Figure 7.

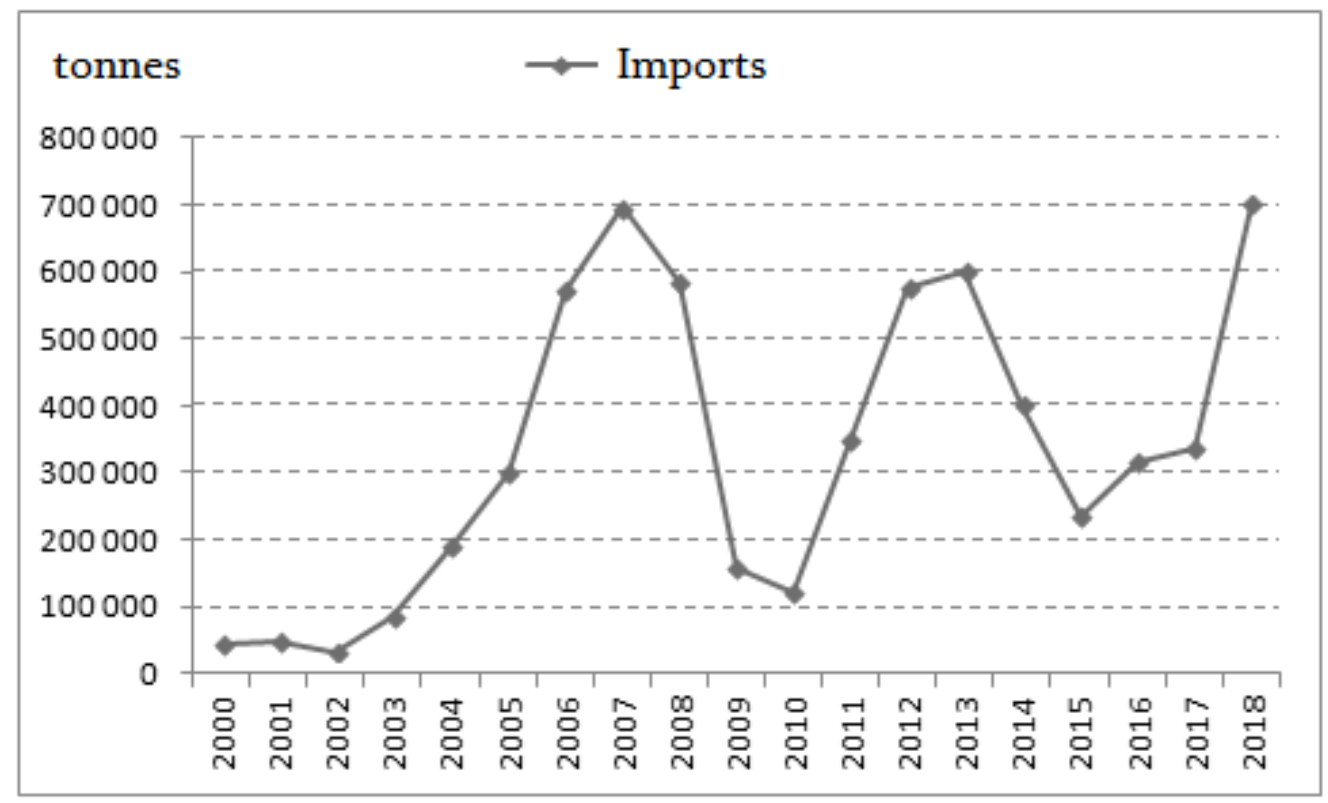

Figure 7. Import of steel into the country from 2000 to 2018. Source: own analyses on the basis of data from Polish Steel Assoctaion in Katowice.

The average annual steel import is 334,000 tonnes. An analysis of the amount of steel imported to Poland in the period from 2000 to 2018 (Fig. 7) indicates that a sharp increase in steel imports occurred in 2007, in 2012 and in 2018. In 2018, the volume of imported steel exceeded the level of 700,000 tonnes - This was the largest amount of imported steel in the analyzed period. Russia and Germany are large steel exporters to Poland. Figure 8 summarizes three trends in total: steel production, steel consumption and steel imports so as to allow the reader to obtain a full picture of fluctuations. Three cycles with high amplitudes of fluctuations from decline to increase and decrease again were obtained (2003-2005, 2004-2009, 2010-2014). In all the analyzed trends, a strong decline in the studied phenomena took place in 2009 (the aforementioned impact on the Polish economy of the effects of the global economic crisis). 


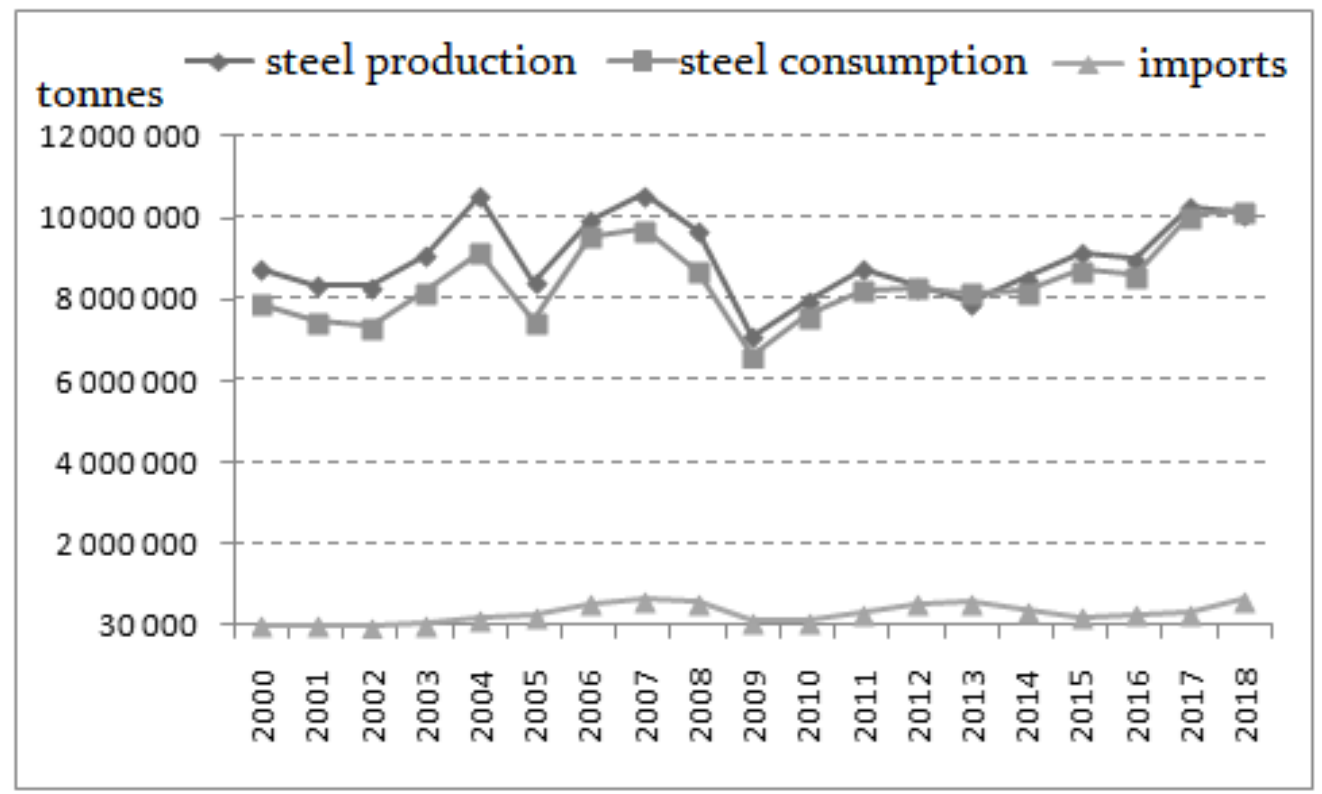

Figure 8. Steel production and steel consumption and imports in Poland in the period from 2000 to 2018. Source: own analyses on the basis of data from Polish Steel Assoctaion in Katowice.

\section{Statistical analysis of trends in steel production and steel consumption}

On the basis of data about steel production and steel consumption in Poland in the period from 2000 to 2018, the functions of trends and forecasts until 2023 are estimated. However, the course of the trend function is difficult to determine due to the occurring periodic fluctuations. Using the trend line options from Excel, a good fit (low $\mathrm{R}^{2}$ index) was not obtained for individual types of trends: linear, exponential, logarithmic, polynomial and power (Gajdzik 2018; Gajdzik, Gawlik, Skoczypiec, 2018).

Based on the historical data obtained, forecasts were made for the volume of steel production and steel consumption until 2023. Classic function and adaptive and autoregression methods were used to develop forecasts. Among the tested methods, the best adjustment of ex post forecasts to empirical data was obtained using the creeping trend method and harmonic weight forecasting. Fig. 9 and 10 show the trends obtained. Forecasts for steel production and steel consumption up to 2023 are summarized in Table 1. The average steel production forecast for the year is 11193867 tonnes, the average steel consumption forecast is for 11190909 tonnes of steel a year.

Table 1.

Forecats of steel production and steel consumption in Poland untill 2023

\begin{tabular}{|c|c|c|c|c|c|}
\hline Year & $\mathbf{2 0 1 9}$ & $\mathbf{2 0 2 0}$ & $\mathbf{2 0 2 1}$ & $\mathbf{2 0 2 2}$ & $\mathbf{2 0 2 3}$ \\
\hline Steel production (tonnes) & 10761819 & 10977843 & 11193867 & 11409891 & 11625915 \\
\hline Steel consumption (tonnes) & 10633512 & 10912210 & 11190909 & 11469608 & 11748306 \\
\hline
\end{tabular}

Source: own analyses. 


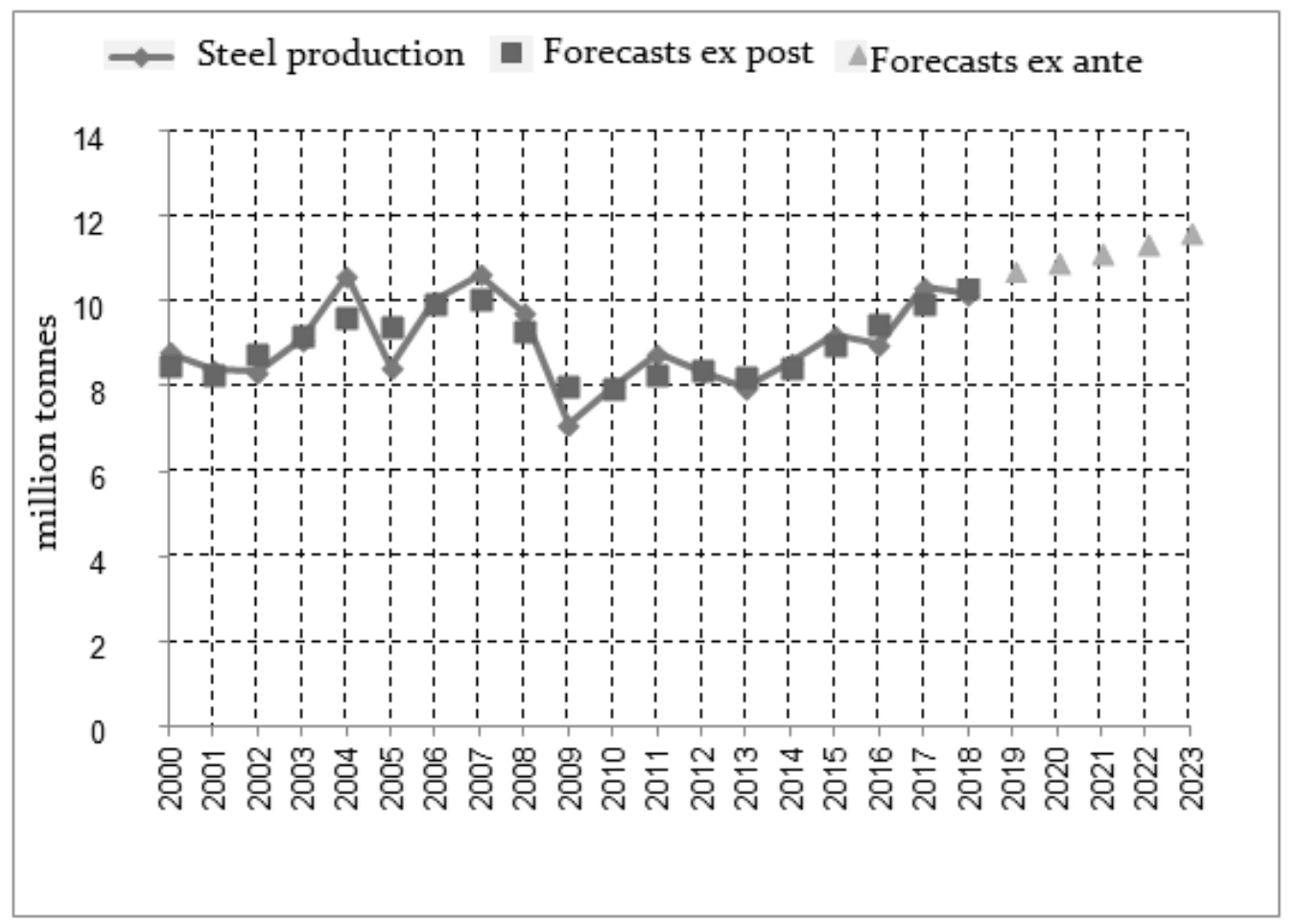

Figure 9. Forecasts of steel production in Poland in the period from 2019 to 2023. Source: own analyses.

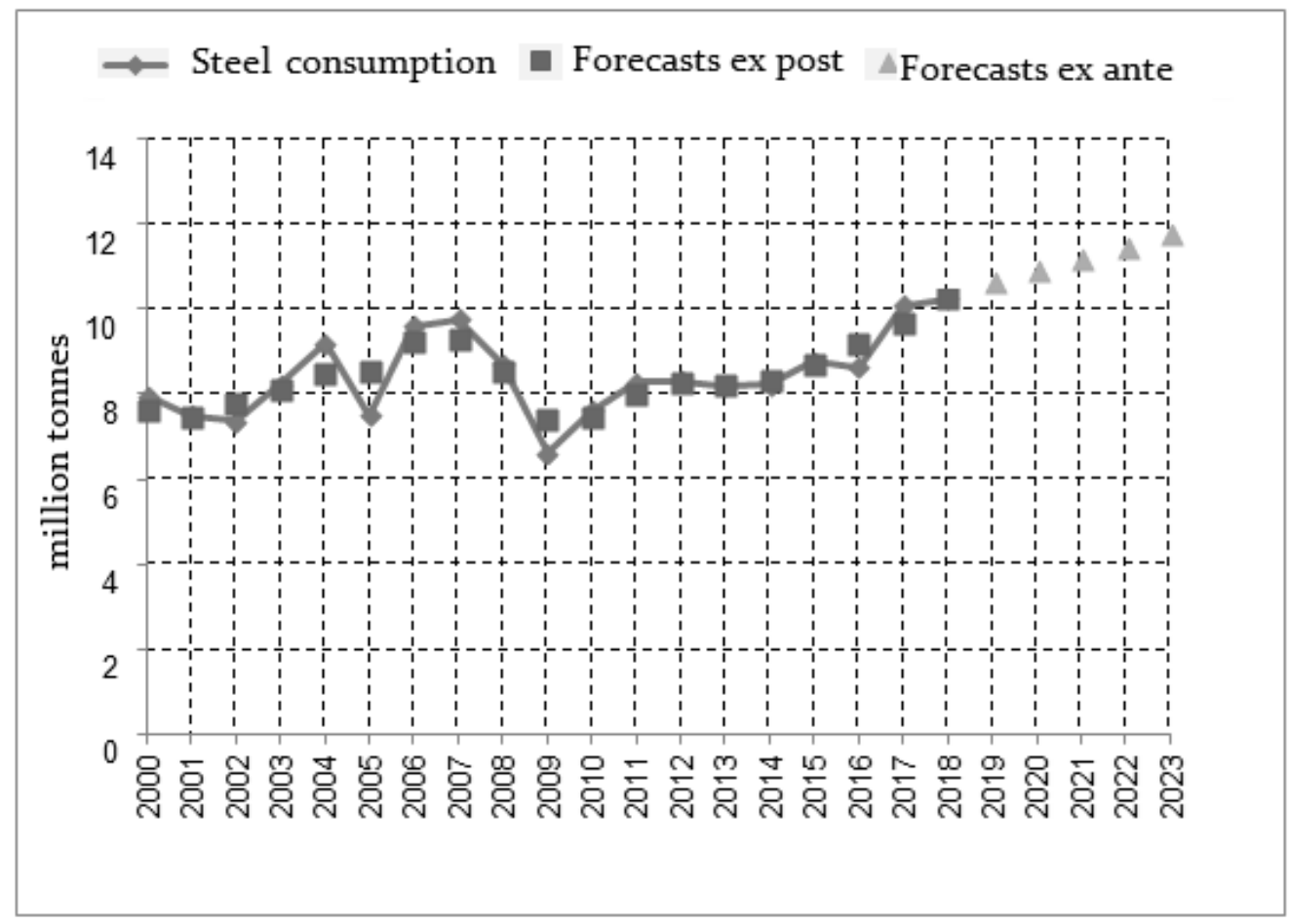

Figure 10. Forecasts of steel consumption in Poland in the period from 2019 to 2023. Source: own analyses. 


\section{Conclusion}

The functioning of the steel industry is strategic for steel-consuming industries and steel user markets. Research on steel production and its consumption in the economy was carried out in the adopted reporting period, which was the period from 2000 to 2018 . The analysis of steel intensity was done in quantitative (numerical) terms. Based on the analysis of the phenomena studied, the following conclusions were made:

- steel production and its consumption is conditioned by the economic situation in the country: an increase or decrease in basic macroeconomic indicators: GDP, consumption, investment, export, import has an impact on the increase or decrease in the volume of produced and consumed steel in the economy,

- the average annual dynamics of basic macroeconomic indicators in Poland from 2000 to 2018 were as follows:

- trends of the phenomena studied (steel production, steel consumption, steel imports) were characterized by strong economic fluctuations that were influenced by the situation in the country and in the world, e.g. the global economic crisis in the years 2008-2009,

- the largest decrease in the amount of steel produced and consumed in Poland was recorded in 2009, this was due to the effects of the global economic crisis that reached Europe which first appeared in the USA,

- the average annual volume of steel production in Poland in the period from 2000 to 2018 was 9 million tonnes; in the same period, the average annual steel consumption in Poland was nearly 8.5 million tonnes, and the average annual steel import to Poland was 334 thousand tonnes,

- the average annual dynamics of the volume (quantity) of steel production in Poland in the period from 2000 to 2018 was almost $+2 \%$ and was lower than the average annual dynamics of the amount of steel consumed in Poland by $0.2 \%$,

- the average forecast for steel production and steel consumption in Poland in period from 2019 to 2023 will be 11.2 million tonnes.

Final conclusion: The favorable economic situation in the country in the period from 2000 to 2018 (conclusion based on the advantage of positive macroeconomic indicators of dynamics of change over negative) has brought about an increase in steel production and its consumption (conclusion based on positive indicators of dynamics of change in production volume and consumption volume), while the dynamics of changes in the economy (referred to as economic growth) was stronger than that in the steel industry (higher level of the analyzed average macroeconomic indicators than the indicators used to characterize the steel sector). 


\section{References}

1. Bednarski, L. (2007). Analiza finansowa w przedsiębiorstwie. Warszawa: PWE.

2. Gajdzik, B., Gawlik, R., Skoczypiec, S. (2018). Forecasting-Scenario-Heuristic method proposal for assessment of feasibility of steel production scenarios in Poland - Managerial implications for production engineering. Archives of Civil and Mechanical Engineering, 18, 1651-1660.

3. Gajdzik, B. (2013a). Changes of action strategies in metallurgical enterprises in time of economic crisis. Metalurgija, 4(52), 569-572.

4. Gajdzik, B. (2013b). The road of Polish steelworks towards market success - changes after restructuring process. Metalurgija, 3(52), 421-424.

5. Gajdzik, B. (2013c). Restrukturyzacja przedsiębiorstw hutniczych $w$ zestawieniach statystycznych i badaniach empirycznych. Gliwice: Wydawnictwo Politechniki Śląskiej.

6. Gajdzik, B. (2014). Crisis management in the metallurgical enterprises. Metalurgija, 3(53), 391-394.

7. Gajdzik, B. (2018). Porestrukturyzacyjne modele funkcji produkcji dla przemysłu hutniczego z prognozami i scenariuszami zmian w wielkości produkcji stali. Gliwice: Wydawnictwo Politechniki Śląskiej.

8. Lista 500, http://www.lista500.polityka.pl/rankings/show/.

9. Ostrowski, A. (2009). Przemysł stalowy. Raport o produkcji hutniczej w Polsce. Magazyn Przemystowy, 10(94).

10. Polski przemyst stalowy. Raport (2018). Katowice: Hutnicza Izba Przemysłowo-Handlowa.

11. Raport Komisji Europejskiej (April 2007). Confidential, monitoring of Commitments Concerning the steel sector in Poland made in the accession negotiations. COMP/2006/SI2.435836, Draft Final Summary Report, Prepared by EuroStrategy Consultants for the European Commission.

12. Szulc, W. (2014). Transformacja polskiego hutnictwa do gospodarki wolnorynkowej (z uzupełnieniem). Prace Instytutu Metalurgii Żelaza, 6. Gliwice.

13. Szulc, W., Garbarz, B., Paduch, J. (2011). Przebieg $i$ wyniki restrukturyzacji przemystu stalowego w Polsce. Prace Instytutu Metalurgii Żelaza, 4, Gliwice, 40-51. 